
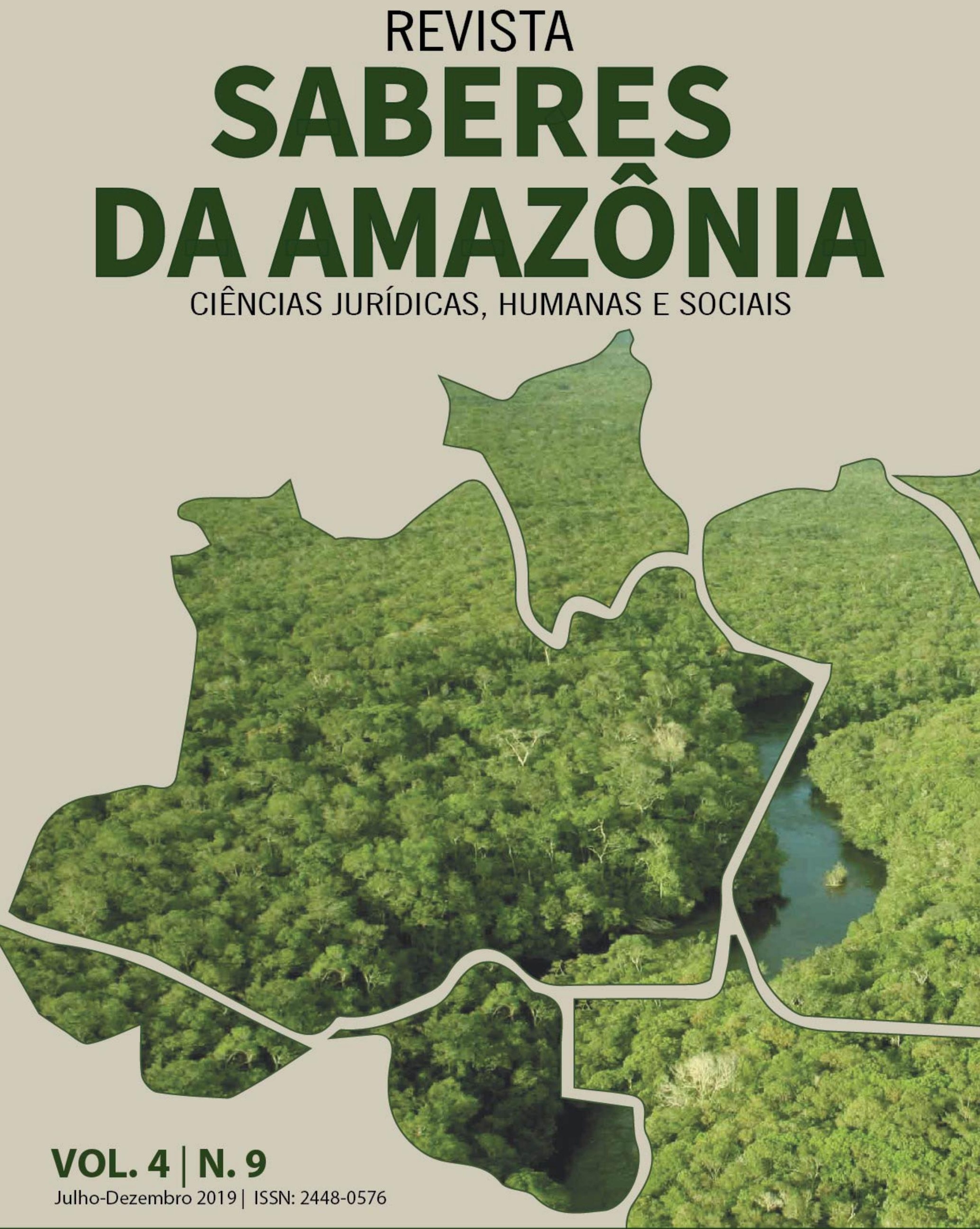


\title{
DO ESTUDO QUANTO A LEGITIMIDADE DA REPRESENTAÇÃO DEMOCRÁTICA EM FACE DAS MANIFESTAÇÕES POPULARES REALIZADAS EM 2013
}

\section{THE STUDY ON THE LEGITIMACY OF DEMOCRATIC REPRESENTATION IN FACE OF THE POPULAR MANIFESTATIONS DONE IN 2013}

\author{
Rocco Antonio Rangel Rosso Nelson ${ }^{1}$ \\ Kamilla Rafaely Rocha de Sena²
}

\section{RESUMO}

A pesquisa em tela, fazendo uso de uma metodologia de análise qualitativa, usandose os métodos de abordagem hipotético-dedutivos de caráter descritivo e analítico, adotando-se técnica de pesquisa bibliográfica, tem por desiderato analisar a crise de legitimidade política vivenciada no cenário nacional, vislumbrada principalmente após as manifestações que retirou da inércia o povo brasileiro. A exposição de alguns conceitos como sociedade, Estado e seus elementos se encaixam de modo a demonstrar a origem da legitimidade de representação política. O Brasil é um país historicamente marcado por crises constitucionais, perfazendo caminhos de evolução democrática e retrocesso a ditaduras. A mais recente Carta Política impede o retorno a regimes autoritários, porém nota-se que o texto produzido não por toda a população, mas por representantes que compunham a cúpula política nacional, apesar de inserir previsões do exercício da soberania popular de forma direta tem permanecido no esquecimento dos representantes políticos, sob o fundamento de suas decisões versarem sobre o bem-estar social. Trata-se não somente de elementos jurídicos inseridos na Constituição Federal, mas também de características históricas-culturais que demonstram a gravidade da inércia dos cidadãos.

PALAVRAS-CHAVE: Constituição. Legitimidade. Democracia representativa.

1 Mestre em Direito. Universidade Federal do Rio Grande do Norte, UFRN. Atualmente, professor efetivo de Direito, no Instituto Federal do Rio Grande do Norte - IFRN. Natal, RN, Brasil. E-mail: rocco.nelson@ifrn.edu.br.

2 Especialista em Direito e Processo do Trabalho. Escola Superior da Magistratura do Trabalho da 21a. Região, ESMAT 21. Natal, RN, Brasil. E-mail: kamillarrsena@hotmail.com. 


\section{ABSTRACT}

On-screen research, using a qualitative analysis methodology, using the hypothetical-deductive approaches of a descriptive and analytical character, adopting a bibliographic research technique, has as a reason to analyze the crisis of political legitimacy experienced in the scenario national, seen mainly after the demonstrations that removed the inertia of the Brazilian people. The exposition of some concepts such as society, state and its elements fit in order to demonstrate the origin of the legitimacy of political representation. Brazil is a country historically marked by constitutional crises, making paths of democratic evolution and regression to dictatorships. The most recent Political Charter prevents the return to authoritarian regimes, but it is noted that the text produced not by the entire population, but by representatives that made up the national political leadership, although inserting forecasts of the exercise of popular sovereignty has remained directly in the forgetfulness of the political representatives, on the basis of their decisions on social welfare. It is not only legal elements inserted in the Federal Constitution, but also historical-cultural characteristics that demonstrate the gravity of the inertia of the citizens.

KEYWORDS: Constitution. Legitimacy. Representative democracy.

\section{DAS CONSIDERAÇÕES INICIAIS}

A abordagem a temas constitucionais é de relevante interesse social visto tratar-se sempre de previsões legais, princípios e fundamentos que direcionam todo o nosso ordenamento jurídico.

É notório que as manifestações populares não se afastam do direito, pois as pessoas exigiram nas ruas o cumprimento das obrigações legais de seus representantes, portanto, inquietando ou provocando juristas a observarem a legitimidade dos atos.

Independentemente a qual dos três poderes se faça referência, o Estado soberano é uno, ocorrendo a tripartição de poderes de modo a melhorar, facilitar e evoluir a administração do país, propondo então a releitura da atual democracia.

Servindo então como ponto de partida para o presente trabalho sobre a legitimidade da representação democrática diante das manifestações populares de 2013, que mais concretamente visa expor as divergências relacionadas à legitimidade dos representantes democráticos na República Federativa Brasileira.

O objetivo dominante deste trabalho é o de discutir as questões que envolvem a legitimidade dos representantes democráticos perante a Constituição Federal do Brasil de 1988. 
Será desdobrado em um crescente demonstrando a evolução histórica do processo de legitimidade política do Brasil, partindo para as modalidades de exercício da soberania popular no regime republicano democrático, incrementando ao documento a definição da democracia representativa e finalmente prosperando para a apresentação das anomalias identificadas no sistema da democracia representativa nacional.

A metodologia utilizada foi a pesquisa bibliográfica, de modo a demonstrar as diretrizes jurídicas e doutrinárias acerca da temática do trabalho.

Guiando o leitor pela inserção e desenvolvimento da legitimidade política no contexto nacional, o trabalho também traz à tona não somente a representatividade governamental, mas ainda a pluralidade na representação política, sendo está o reconhecimento e aceitação da presença dos representantes de todos os segmentos e interesses populares na Administração Pública.

Art. $1^{\circ}$ A República Federativa do Brasil, formada pela união indissolúvel dos Estados e Municípios e do Distrito Federal, constitui-se em Estado Democrático de Direito e tem como fundamentos:

I - a soberania;

II - a cidadania;

III - a dignidade da pessoa humana;

IV - os valores sociais do trabalho e da livre iniciativa;

$\mathrm{V}$ - o pluralismo político.

Parágrafo único. Todo o poder emana do povo, que o exerce por meio de representantes eleitos ou diretamente, nos termos desta Constituição.

Voltando a atenção deste documento para o olhar jurídico do problema da (des)lealdade dos representantes políticos ao contrato social de força maior no sistema jurídico nacional.

Seguindo pela exposição e conceituação das formas de realização prática da soberania popular na democracia brasileira, inseridas pela Constituição Federal de 1988 que é um marco na história nacional ao mudar de um estado opressor, regime militar, para um estado democrático representativo conforme a Carta Magna assevera, inserindo por essa o neoconstitucionalismo.

Como resultado a Constituição Federal de 1988 reservou um título para os direitos e garantias fundamentais, sem afastar-se da visão legalista, porém aproximando-se do ideal de se compreender o contexto. 
Partindo para o conceito do modelo de democracia adotado no Brasil, diga-se a democracia representativa, esta esclarece que aos governantes é dado o poder de representação do povo, sendo legitimados para o exercício do poder.

Alguns doutrinadores constitucionais defendem que o atual modelo de democracia está ultrapassado, pois a evolução social caminha para o modelo de democracia participativa, esta que seria um modelo de maior intervenção social, ou seja, o legítimo exercício do poder soberano do povo.

Tomando como desfecho a ideia da representação democrática ser o exercício do povo através de representantes é fácil de verificar anomalias junto ao modelo democrático brasileiro estando na existência de institutos jurídicos como a imunidade parlamentar e o foro privilegiado, que foram inseridos pelo poder Constituinte, este apesar de ter havido a participação popular fora concretizado por um pequeno grupo.

Após então a apresentação das aberrações identificadas na democracia representativa nacional, permitirá ao leitor uma reflexão jurídica acerca do "despertar do gigante" e dos problemas entranhados na cultura política do Brasil.

\section{EVOLUÇÃO HISTÓRICA DO PROCESSO DE LEGITIMIDADE POLITICA}

\subsection{SOCIEDADE}

Desde o momento que o homem passou a viver em grupo notou-se a necessidade da existência de uma organização, de modo que garantisse, embora de forma primitiva, a ideia de pacificação social.

Estes grupos passaram a formar então sociedades, que sob uma perspectiva geral será "todo complexo de relações do homem com seus semelhantes"3.

Karl Marx compreende a sociedade como um só, sem conceber nenhuma oposição ou distinção entre o indivíduo e a sociedade, trazendo ao indivíduo a característica de um ser social ${ }^{4}$.

Paulo Bonavides afirma que "Na doutrina aristotélica assinala-se, com efeito, o caráter social do homem. A natureza fez do homem o "ser político", que não pode viver fora da Sociedade." 5 .

3 Parsons apud Bonavides, Paulo. Ciência Política. 10 ed. São Paulo: Malheiros, 2001, pág. 54. 4 DICIONÁRIO do pensamento Marxista. Rio de Janeiro: Zahar Editores, 2001. 
No interior do conceito de sociedade ocorre ainda uma subdivisão desta concepção, trazendo à tona uma noção de sociedade mecânica e orgânica.

A primeira pode ser compreendida como sendo um grupo que compartilham de interesses, princípios, costumes e noções, com uma característica marcante de se não houver aqueles componentes aquela sociedade também não existe, tudo será orientado pelo interesse do indivíduo, muito comum nas sociedades primitivas. ${ }^{6}$

Enquanto que a sociedade orgânica é formada por indivíduos que contribuem para o desenvolvimento do todo, onde a individualidade é mantida mesmo que se conviva em grupo, porém a sociedade em si tem mais valor do que o indivíduo, facilmente compreendida quando se nota a sociedade capitalista, onde todos são diferentes, cada um exercendo sua função, preenchendo seu espaço, convivendo pacificamente cada um com seu interesse e valor, regidos por códigos e regras de conduta, ou seja, pelo direito.

Bonavides esclarece que na sociedade orgânica restando o poder ser de fato dado a cada indivíduo "acabaria gerando o despotismo das multidões"7 findando então a sociedade em um regime ditatorial, trazendo à tona o entendimento de que o indivíduo conhece da autoridade desde o seu nascimento, portanto dela se necessita para que se sobreviva em harmonia com o meio, assim Bonavides instruiu:

Fazem os organicistas a apologia da autoridade. Estimam o social porque vêem na Sociedade 0 fato permanente, a realidade que sobrevive, a organização superior, o ordenamento que, desfalcado dos indivíduos na sucessão dos tempos, no lento desdobrar das gerações, sempre persiste, nunca desaparece, atravessando o tempo e as idades. Os indivíduos passam, a Sociedade fica. ${ }^{8}$

Sendo o indivíduo o centro da sociedade, esta será continuada pela independência dos homens que a compõem, permitindo a mutação social, ou seja, um indivíduo pode ascender ou declinar perante a sociedade. Destas teorias acerca da sociedade é que se tem a origem da legitimação do poder democrático, que segundo Paulo Bonavides, "a base da sociedade é o assentimento e não o princípio

5 Bonavides, Paulo. Ciência Política. 10 ed. São Paulo: Malheiros, 2001, pág. 55.

6 Durkheim apud Bodart, Cristiano. Solidariedade Mecânica e Solidariedade Orgânica. Site Café com Sociologia. Disponível em: <http://www.cafecomsociologia.com/2011/01/solidariedade-mecanica-esolidariedade.htm>. Acesso em: 10/2013.

7 Bonavides, Paulo. Ciência Política. 10 ed. São Paulo: Malheiros, 2001, pág. 56.

8 Bonavides, Paulo. Ciência Política. 10 ed. São Paulo: Malheiros, 2001, pág. 56. 
de autoridade"9, tornando claro que independentemente do tipo de representação política o Povo é quem, em tese, detém o poder da soberania do Estado.

Após a formação e entendimento do conceito de sociedade, é mister a compreensão da definição do Estado, e os seus elementos, é o que passamos a fazer.

\subsection{Estado}

É primordial destacar que a concepção de Estado exposta será a que apresenta conotação e relevância jurídica, dada a vasta lista de correntes teóricas a respeito da origem e formação do Estado, que findam com as mais diversas e divergentes conclusões.

Inicialmente o jusnaturalismo distinguia sociedade civil de sociedade natural, sendo aquela primeira sinônima de Estado, importando que este somente surgisse pela necessidade de garantir direitos individuais, que na sociedade natural são comprometidos, pois os conflitos são dirimidos pela autotutela. ${ }^{10}$

Dalmo de Abreu Dallari afirma que o estado em sua concepção de sociedade política foi assim denominado primeiramente por Maquiavel, em sua obra "O Príncipe" em 1513, passando a ser aceito aos poucos durante os séculos XVI e XVII pela comunidade europeia. ${ }^{11}$

Quando então advêm as teorias acerca da origem e constituição do Estado, Dallari reduz a três principais no tocante a origem, sendo:

O Estado como sinônimo de sociedade, devido a integração social do homem, com capacidade de liderar e admitir o poder. $^{12}$

A segunda forma revela a sociedade sem formação de Estado, sendo que este fora constituído para atender os interesses dos grupos sociais. ${ }^{13}$

9 Bonavides, Paulo. Ciência Política. $10^{\circ}$ ed. São Paulo: Malheiros, 2001, pág. 58.

10 BOBBIO, Norberto; MATTEUCCI, Nicola; PASQUINO, Gianfranco. Dicionário de política: volume 2: L-Z. 12. ed. Brasília: Universidade de Brasília, 2004, pág. 1206.

11 Dallari, Dalmo de Abreu. Elementos de Teoria Geral do Estado. 30 ed. São Paulo: Saraiva. 2011, pág. 59

12 Dallari, Dalmo de Abreu. Elementos de Teoria Geral do Estado. 30 ed. São Paulo: Saraiva. 2011, pág. 60

13 Dallari, Dalmo de Abreu. Elementos de Teoria Geral do Estado. 30 ed. São Paulo: Saraiva. 2011, pág. 60. 
A terceira, e mais comumente aceita no âmbito jurídico, é a que considera Estado as sociedades políticas, dotadas de soberania, território e povo, elementos que serão tratados um pouco mais adiante. ${ }^{14}$

Esta última concepção demonstra compatibilidade com o conceito de Estado sugerido por Hans Kelsen, que afirma ser o Estado um sistema de normas as quais os indivíduos estão sujeitos a elas, ainda que antagônicas a vontade de cada ser. ${ }^{15}$

Ainda existem as teorias não contratualistas, porém por se aterem ao fator econômico não serão tratadas neste documento.

Para compreender o Estado Moderno e como ele concebeu sua atual formação, é imprescindível que se faça uma remissão à história da sociedade ocidental. Iniciando, portanto pelo Estado na Antiguidade.

O Estado Antigo é a mais remota forma de Estado, trata-se de uma época em que o Estado se confundia com a organização econômica ${ }^{16}$ e fundamentava-se no fator religioso.

Ainda a respeito do Estado Antigo, Paulo Bonavides o resume como:

[...] O Estado Antigo: numa extremidade a força bruta das tiranias imperiais típicas do Oriente; noutra, a onipotência consuetudinária do Direito ao fazer suprema, em certa maneira, a vontade do corpo social, qualitativamente cifrado na ética teológica da pólis grega ou no zelo sagrado da coisa pública, a res publica das civitas romana. ${ }^{17}$

Apesar da não limitação ou definição clara e concreta dos elementos do Estado o momento não fora obscuro a evolução social.

Do Estado Antigo seguimos para o Estado na Idade Média, momento histórico de notória descentralização do poder, pois no mundo medievo prevaleceu a organização feudal, desconstituindo a organização governamental da Antiguidade e integrando o Poder a cada feudo ${ }^{18}$, ou melhor, a cada senhor feudal.

A respeito do Estado na Idade Média, Dallari afirma que:

14 Dallari, Dalmo de Abreu. Elementos de Teoria Geral do Estado. $30^{\circ}$ ed. São Paulo: Saraiva. 2011, pág. 60.

15 KELSEN, Hans. Teoria Geral do Direito e Do Estado. $4^{\circ}$ ed. São Paulo: Martins Fontes, 2005. Pág. 273.

16 KELSEN, Hans. Teoria Geral do Direito e Do Estado. $4^{\circ}$ ed. São Paulo: Martins Fontes, 2005, pág. 70.

17 BONAVIDES, Paulo. Teoria do Estado. $7^{\circ}$ ed. São Paulo: Malheiros, 2008, Pág. 32.

18 BONAVIDES, Paulo. Teoria do Estado. $7^{\circ}$ ed. São Paulo: Malheiros, 2008, Pág. 32. 
Formalmente, a unidade política superior é o Império, sem que haja, na prática, uma autoridade e uma ordem correspondentes. A luta entre o Papa e o Imperador, que marcaria os últimos séculos da Idade Média, só vai terminar com o nascimento do Estado Moderno, quando se afirma a supremacia absoluta dos monarcas na ordem temporal. ${ }^{19}$

Visto a colocação de Dallari é público e sabido a força do Cristianismo na era medieval, e apesar de toda descentralização de organização jurídica-política é o Cristianismo que inspira a unidade do poder, com implícitos anseios políticos dominadores por aqueles que constituíam a igreja.

As mais diversas ordens jurídicas ditadas por cada senhor feudal, as invasões e guerras interiores, tornaram-se barreiras ao desenvolvimento do comércio, favorecendo ideais que logo passaram a caracterizar o Estado Moderno.

A respeito do Estado Medieval Bonavides é menos brando, compreendendo que o Estado, no sentido atual, teve seu poder e elementos enfraquecidos pela organização feudal. ${ }^{20}$

Dallari ainda esclarece que vivenciar a descentralização de poder do Estado Medieval, favoreceu a conscientização para aceitação e criação da unidade do Estado. O Estado Moderno manifestou-se então pelo reconhecimento de um poder soberano, admitindo a hierarquia daquele poder perante os demais, em determinada delimitação territorial. ${ }^{21}$

A soberania é tratada por Bonavides como fundamento do Estado Moderno, como autoridade legitimada a um governante, monarca, príncipe, ou qualquer outro indivíduo a quem seja dado o poder, a qual todos se sujeitam ${ }^{22}$.

Tratando-se então dos elementos constitutivos do Estado Moderno, são divergentes as teorias acerca da quantidade e definição dos elementos, porém os quatros mais comuns são identificados por Dallari, sendo: a soberania, o território, o povo e a finalidade.

A soberania permanece conforme a ideia já exposta, de ser o poder supremo, aquele a qual os indivíduos que estão em determinado território estão submetidos, e no âmbito internacional entendida como "capacidade de entrar em relações com os

19 DALLARI, Dalmo de Abreu. Elementos de Teoria Geral do Estado. $30^{\circ}$ ed. São Paulo: Saraiva, 2011. Pág. 74

20 BONAVIDES, Paulo. Teoria do Estado. $7^{\circ}$ ed. São Paulo: Malheiros, 2008, pág. 32

21 DALLARI, Dalmo de Abreu. Elementos de Teoria Geral do Estado. $30^{\circ}$ ed. São Paulo: Saraiva, 2011. Pág. 78

22 BONAVIDES, Paulo. Teoria do Estado. $7^{\circ}$ ed. São Paulo: Malheiros, 2008, pág. 33 
demais Estados"23, assim prevista na Convenção Pan-americana sobre Direitos e Deveres dos Estados ${ }^{24}$.

Miguel Reale conceitua a soberania como "o poder que tem uma Nação de organizar-se livremente e de fazer valer dentro de seu território a universalidade de suas decisões para a realização do bem comum" 25 , reafirmando a existência de uma determinada hierarquia a qual os indivíduos submetem-se.

Atualmente a soberania tem sido conceituada como sinônimo de independência de determinados Estados perante a qualquer potência estrangeira, assim afirma Dallari, buscando então uma autonomia sobre seu território, baseandose no respeito como regra de convivência com a sociedade internacional. ${ }^{26}$

O segundo elemento constitutivo do Estado é o território que segundo Hans Kelsen "nada mais é que a esfera territorial de validade da ordem jurídica chamada Estado" 27 , ou seja, o território não obrigatoriamente deve ser continuo, exige-se que o respeito a ordem seja definido por um Estado preciso.

Ainda a respeito do território Dallari explica que este vem a delimitar a "ação soberana do Estado"28, ou seja, validando no seu território a ordem jurídica como suprema, a qual qualquer norma jurídica exterior estará sujeita a prévia avaliação antes de sua aceitação ao ordenamento jurídico.

Integra ainda o Estado o elemento Povo, que para alguns autores é sinônimo de população ou nação, porém Dallari afirma que existem diferenças ${ }^{29}$,

23 Art. $1^{\circ}, \mathrm{d}$, Convenção Pan-americana sobre Direitos e Deveres dos Estados. Disponível em << http://orange.grupobarman.com/diplomacia/diplorange/convencao_1933.htm >> acesso em 03/2014. 24 O Brasil é signatário da Convenção Pan-americana sobre Direitos e Deveres dos Estados, assinadas em Montevidéu, em 26 de dezembro de 1933, pela promulgação do Decreto $n^{\circ} 1.570$, de 13 de abril de 1937.

25 REALE, Miguel. Teoria do Direito e do Estado. $5^{\circ}$ ed. São Paulo: Saraiva, 2000, pág. 140.

26 DALLARI, Dalmo de Abreu. Elementos de Teoria Geral do Estado. $30^{\circ}$ ed. São Paulo: Saraiva, 2011 , pág. 90.

27 KELSEN, Hans. Teoria Geral do Direito e do Estado. $3^{\circ}$ ed. São Paulo: Martins Fontes, 1998. Pág. 300.

28 DALLARI, Dalmo de Abreu. Elementos de Teoria Geral do Estado. $30^{\circ}$ ed. São Paulo: Saraiva, 2011, pág. 95

29 Considera-se por população "mera expressão numérica, demográfica, ou econômica, segundo Marcello Caetano, que abrange o conjunto das pessoas que vivem no território de um Estado ou mesmo que se acham nele temporariamente." Nação: expressão usada inicialmente para indicar origem comum, ou comunidade de nascimento do indivíduo. (DALLARI, Dalmo de Abreu. Elementos de Teoria Geral do Estado. $30^{\circ}$ ed. São Paulo: Saraiva, 2011, pág. 100 - 101). Para Miguel Reale, a nação é formada por múltiplos fatores objetivos, culturais e históricos que formam a comunhão dos homens de um mesmo território. (REALE, Miguel. Teoria do Direito e do Estado. $5^{\circ}$ ed. São Paulo: Saraiva, 2000, Miguel Reale, 2000, págs. 133 -134). 
caracterizando o uso genérico uma forma errônea de referir-se ao Povo como elemento constitutivo do Estado.

Kelsen define o povo de modo simples, como sendo a esfera pessoal de validade da ordem jurídica, considerando ser o povo uma unidade no Estado. ${ }^{30}$ Dallari conceitua o povo como:

O conjunto dos indivíduos que, através de um momento jurídico, se unem para constituir o Estado, estabelecendo com este um vínculo jurídico de caráter permanente, participando da formação da vontade do Estado e do exercício do poder soberano. ${ }^{31}$

Permanecendo com a ideia de unidade explanada por Kelsen, porém sendo um elemento ativo mesmo após a constituição e reconhecimento da soberania do Estado.

Por fim, o elemento finalidade que se demonstra de forma controversa por não ser unanime entre os autores, mas se expõe no fato que o Estado deve buscar seus objetivos de modo a proporcionar aos indivíduos que alcancem seus propósitos, "o bem comum de certo povo, situado em determinado território"32 esclareceu Dallari.

Com todos os elementos constitutivos do Estado delineados é notória a presença de uma autoridade que representa o Estado, o Povo como estado, um superior que direciona e governa de modo a atingir a finalidade do bem comum, que representa o Estado para a comunidade política internacional, porém o exercício dessa representatividade não se dá de forma livre e espontânea, geralmente existe um documento jurídico que garante a legitimidade desses atos.

\subsection{Caracterização da Constituição Federal como documento jurídico}

Como elemento constitutivo do Estado destacou-se a soberania, o poder supremo ao qual todas as pessoas estão sujeitas, e com o surgimento do Estado Moderno notou-se o que se denomina de constitucionalismo, que não se trata

30 KELSEN, Hans. Teoria Geral do Direito e do Estado. $3^{\circ}$ ed. São Paulo: Martins Fontes, 1998, pág. 334.

31 DALLARI, Dalmo de Abreu. Elementos de Teoria Geral do Estado. 30 ed. São Paulo: Saraiva, 2011. Pág. 104

32 DALLARI, Dalmo de Abreu. Elementos de Teoria Geral do Estado. 30 ed. São Paulo: Saraiva, 2011, pág. 112 
apenas de garantir a liberdade dos indivíduos, mas de um princípio mantenedor dos limites do governo imprescindível à garantia dos direitos. ${ }^{33}$

Para André Ramos Tavares o constitucionalismo tem seu aspecto jurídico revelado "pela pregação de um sistema dotado de um corpo normativo máximo, que se encontra acima dos próprios governantes - a Constituição" ${ }^{34}$, um documento legitimo e que expõe a força e soberania do Estado como figura despersonalizada de modo a impedir que se governe por atos de vontades pessoais.

No Constitucionalismo moderno fica nítida a ideia de que o documento garantidor se denomina Constituição, pois esta, segundo Canotilho, já fora um documento formado por "um conjunto de regras (escritas ou consuetudinárias) e de estruturas institucionais conformadoras de uma dada ordem jurídico-política num determinado sistema político social"35.

A doutrina esclarece ainda que a modernidade trouxe a peculiaridade de serem as Constituições escritas ${ }^{36}$, onde, conforme assevera Canotilho, estão inseridas "as liberdades e os direitos e se fixam os limites do poder político"37

Tornando nítido que na era do Constitucionalismo moderno existe um documento de força superior que rege, direciona e ordena todo o ordenamento jurídico de um Estado.

André Ramos Tavares esclarece que no surgimento do constitucionalismo, no século XIX o conceito atrelado a constituição fora o ideológico político-liberal ${ }^{38}$, diante do quadro histórico de poderosos governantes que exploraram o povo, e nada-lhes devolveu até suas conhecidas manifestações históricas.

As revoluções na França permitiram a formação de uma Constituição, baseando-se na individualidade dos homens, porém em sua igualdade de direitos, rompendo toda e qualquer ligação com o antigo regime, de modo a almejar uma nova ordem social.

33 CANOTILHO, J. Joaquim Gomes. Direito Constitucional e Teoria da Constituição. $7^{a}$ ed. Coimbra: Almedina, 2003. Pág. 51

34 TAVARES, André Ramos. Curso de Direito Constitucional. 8 ed. São Paulo: Saraiva, 2010. Pág. 25.

35 Willoweit apud Canotilho, J.J. Gomes. Direito Constitucional e Teoria da Constituição. $7^{a}$ ed.Coimbra: Almedina, 2003. Pág. 53

36 Lassalle apud Bonavides, Paulo. Curso de Direito Constitucional. 28. ed. atual. São Paulo: Malheiros Editores, 2013. Pág 85

37 Canotilho, J.J. Gomes. Direito Constitucional e Teoria da Constituição. 7 ed. Coimbra: Almedina, 2003. Pág. 52

38 TAVARES, André Ramos. Curso de Direito Constitucional. 8 ed. São Paulo: Saraiva, 2010, pág. 85 
A vontade de estabelecer uma nova ordem reflete então acerca da legitimação do poder político ${ }^{39}$. A fundação de um novo modelo político social passou a depender de uma espécie de contrato social, de modo a assegurar a liberdade individual bem como o funcionamento da ordem política, é quando surge ainda na França o poder constituinte..$^{40}$

A nova forma de poder difundida pelas ideias revolucionarias iluministas ocasionam a teoria da legitimidade do poder, que segundo Bonavides apresentou-se compreendida "nos conceitos de soberania nacional e soberania popular" 41 , proporcionando o surgimento da teoria do poder constituinte.

O poder constituinte segundo André Ramos Tavares é o soberano que dita a ordem jurídica constante da Carta Magna ${ }^{42}$, Canotilho complementa a esta ideia anunciando que o poder constituinte revela em si uma força apta a originar uma Constituição ${ }^{43}$. Paulo Bonavides esclarece que o poder constituinte sempre existiu dado que as sociedades sempre atuaram de modo a se organizarem baseando-se em seus fundamentos, a diferença está na teoria do poder constituinte, que surge ao final do século XVIII ${ }^{44}$.

Da teoria compreende-se então o surgimento do poder constituinte nacional, que Bonavides o descreve como "a soberania a serviço do sistema representativo" 45 , diante do poder constituinte e da teoria deste surge então a constituição, como documento que rege todo um Estado, buscando de forma democrática a "autodeterminação e auto-organização de uma coletividade"46.

Diante do poder constituinte e da Constituição por ele elaborada é concebível a ideia de que a Carta Magna terá como fundamento o exercício da soberania

39 CANOTILHO, J.J. Gomes. Direito Constitucional e Teoria da Constituição. $7^{\circ}$ ed. Coimbra: Almedina, 2003, pág. 57.

40 CANOTILHO, J.J. Gomes. Direito Constitucional e Teoria da Constituição. $7^{\circ}$ ed. Coimbra: Almedina, 2003, pág. 58.

41 BONAVIDES, Paulo. Curso de Direito Constitucional. $28^{\circ}$ ed. São Paulo: Malheiros editores, 2013. Pág. 147.

42 TAVARES, André Ramos. Curso de Direito Constitucional. $8^{\circ}$ ed. São Paulo: Saraiva, 2010. Pág. 51.

43 CANOTILHO, J.J. Gomes. Direito Constitucional e Teoria da Constituição. 7 ed. Coimbra: Almedina, 2003, pág. 65.

44 BONAVIDES, Paulo. Curso de Direito Constitucional. $28^{\circ}$ ed. São Paulo: Malheiros editores, 2013, pág. 148.

45 BONAVIDES, Paulo. Curso de Direito Constitucional. $28^{\circ}$ ed. São Paulo: Malheiros editores, 2013 , pág. 149.

46 CANOTILHO, J.J. Gomes. Direito Constitucional e Teoria da Constituição. $7^{\circ}$ ed. Coimbra: Almedina, 2003, pág. 67. 
popular, quando então se insere a participação do povo no Estado, direta ou indiretamente.

\section{EXERCÍCIO DA SOBERANIA POPULAR NO REGIME REPUBLICANO DO BRASIL}

\subsection{FORMAS DE GOVERNO}

Diversas são as formas de governo classificadas na história, o critério mais utilizado e que expõe as classificações mais aceitas é o do número de titulares do poder soberano ${ }^{47}$.

Kelsen é direto em afirmar que o governo de um só é uma monarquia ${ }^{48}$, Bonavides se firmando no conceito de Aristóteles complementa que se trata de pretensão do sistema monárquico a atribuição de poder a uma única pessoa ${ }^{49}$.

Aristóteles assenta que a monarquia é o poder conferido a um só, referenciando ao exercício e comando de um pai de família que em sua casa tudo governa ${ }^{50}$.

A característica a que se faz referência demonstra ainda que quando o governo pertence a diversas pessoas, intitula-se de república, Kelsen segue a linha de entendimento de Maquiavel, quando divide a forma republicana em aristocracia ou uma democracia 51

A primeira sendo o governo de poucos, porém de um número plural, o que diferencia da monarquia ${ }^{52}$, ainda sobre a aristocracia Aristóteles expõe o pensamento de ser o regime dos bons, onde somente aos virtuosos é conferido o poder soberano do Estado ${ }^{53}$.

47 BONAVIDES, Paulo. Ciência Política. $10^{\circ}$ ed. São Paulo: Malheiros, 2001. Pág. 192 -193.

48 KELSEN, Hans. Teoria Geral do Direito e do Estado. $3^{\circ}$ ed. São Paulo: Martins Fontes, 1998. Pág 405.

49 BONAVIDES, Paulo. Ciência Política. $10^{\circ}$ ed. São Paulo: Malheiros, 2001, pág. 193.

50 ARISTÓTELES. A política. Traduzido por Roberto Leal Ferreira. $3^{\circ}$ ed São Paulo: Martins Fontes, 2006. Pág. 112

51 KELSEN, Hans. Teoria Geral do Direito e do Estado. $3^{\circ}$ ed. São Paulo: Martins Fontes, 1998, pág 405; MAQUIAVEL apud BONAVIDES, Paulo. Teoria Geral do Direito e do Estado. $3^{\circ}$ ed. São Paulo: Martins Fontes, 1998, pág 195.

52 KELSEN, Hans. Teoria Geral do Direito e do Estado. $3^{\circ}$ ed. São Paulo: Martins Fontes, 2000. Págs. 406 e 407.

53 ARISTÓTELES. A política. Traduzido por Roberto Leal Ferreira. $3^{\circ}$ ed São Paulo: Martins Fontes, 2006. Págs. 112 e 113. 
A segunda forma em número maior de governantes é exercida pela representação de um povo livre, onde os sujeitos reconhecem a existência e prevalência do princípio democrático no Estado ${ }^{54}$.

A república é por Aristóteles definida como uma fusão de regimes falhos, que permite extrair o que houver de melhor em cada um, havendo a combinação "dos pobres com os ricos" 55 .

No direito eleitoral, a doutrina de José Jairo Gomes assevera ser república a forma de governo onde os governantes são eleitos, permanecendo no exercício do poder por tempo determinado (temporalidade), o que induz a alternância do poder, pois deve haver vedação a reeleições contínuas que favoreçam qualquer ofensa aos fundamentos da república ${ }^{56}$

O Brasil adotou a forma de governo republicana democrática conforme faz prova a Constituição Federal desde o seu preâmbulo quando o poder constituinte declara ser representante do povo brasileiro para instituir o Estado Democrático, sendo tal forma reafirmada no caput do artigo $1^{\circ}$ do Supremo Texto Constitucional ${ }^{57}$, assegurando, portanto, a participação dos cidadãos, na formação do Estado. ${ }^{58}$

A garantia constitucional de obediência ao princípio republicano encontra-se também no artigo 82 da Constituição Federal de 1988, que rege sobre o tempo de mandato do Presidente da República, ou seja, do chefe do poder executivo. Observando-se a mesma referência temporal para as funções de chefia do poder

54 KELSEN, Hans. Teoria Geral do Direito e do Estado. 3 ed. São Paulo: Martins Fontes, 2000. Págs. 406 e 407.

55 ARISTÓTELES. A política. Traduzido por Roberto Leal Ferreira. $3^{\circ}$ ed São Paulo: Martins Fontes, 2006, Pág. 115.

56 Fundamentos da república, conforme José Jairo Gomes são "a eletividade, a temporalidade e a alternância de pessoas no comando do Estado.". (GOMES, José Jairo. Direito Eleitoral. $5^{\circ}$ ed. Belo Horizonte: Del Rey, 2010. Pág. 37).

57 Preâmbulo: Nós, representantes do povo brasileiro, reunidos em Assembléia Nacional Constituinte para instituir um Estado Democrático, destinado a assegurar o exercício dos direitos sociais e individuais, a liberdade, a segurança, o bem-estar, o desenvolvimento, a igualdade e a justiça como valores supremos de uma sociedade fraterna, pluralista e sem preconceitos, fundada na harmonia social e comprometida, na ordem interna e internacional, com a solução pacífica das controvérsias, promulgamos, sob a proteção de Deus, a seguinte CONSTITUIÇÃO DA REPÚBLICA FEDERATIVA DO BRASIL.

(...)

Art. $1^{\circ} \mathrm{A}$ República Federativa do Brasil, formada pela união indissolúvel dos Estados e Municípios e do Distrito Federal, constitui-se em Estado Democrático de Direito e tem como fundamentos: (Constituição Federal de 1988)

58 GOMES, José Jairo. Direito Eleitoral. 5 ed. Belo Horizonte: Del Rey, 2010, pág. 36. 
executivo a nível estadual e municipal, bem como as funções legislativas, com exceção ao cargo de Senador, cujo mandato é de oito anos ${ }^{59}$.

Diante da temporalidade dos cargos, característica fundamental da república, é necessária a participação da população na escolha dos governantes, tal poder é comumente conhecido como soberania popular, segue-se então sobre.

\subsection{Soberania Popular: conceito e exercício.}

Neste momento o termo soberania como elemento constitutivo do Estado será um pouco afastado, sendo oportuno evocar agora o termo soberania popular, que no Brasil encontra seu fundamento jurídico na Constituição Federal de 1988, em seu artigo $1^{\circ}$, parágrafo único ${ }^{60}$, e sua forma de exercício apresentada no artigo 14 , caput, do mesmo diploma ${ }^{61}$.

O poder soberano do Estado democrático emana do povo, seja ele exercido diretamente ou por meio de representantes, assim leciona José Jairo Gomes ${ }^{62}$. Compatível a esta ideia Dallari afirma que o fundamento da soberania popular é requisito do Estado Democrático, o que garante ao povo o "autogoverno"63, exercido quando pelo voto ${ }^{64}$.

59 Previsões constitucionais a respeito dos cargos do executivo e legislativo.

Art. 28. A eleição do Governador e do Vice-Governador de Estado, para mandato de quatro anos, (...) - Constituição Federal de 1988.

Art. 29. O Município reger-se-á por lei orgânica, (...)

I - eleição do Prefeito, do Vice-Prefeito e dos Vereadores, para mandato de quatro anos, mediante pleito direto e simultâneo realizado em todo o País; -

Art. 27. O número de Deputados à Assembléia Legislativa (...)

$\S 1^{\circ}$ - Será de quatro anos o mandato dos Deputados Estaduais, (...)

Art. 44. O Poder Legislativo é exercido pelo Congresso Nacional, que se compõe da Câmara dos Deputados e do Senado Federal.

Parágrafo único. Cada legislatura terá a duração de quatro anos.

Art. 46. O Senado Federal compõe-se de representantes dos Estados e do Distrito Federal, eleitos segundo o princípio majoritário.

$\S 1^{\circ}$ - Cada Estado e o Distrito Federal elegerão três Senadores, com mandato de oito anos.

60 Art. $1^{\circ}$ A República Federativa do Brasil, formada pela união indissolúvel dos Estados e Municípios e do Distrito Federal, constitui-se em Estado Democrático de Direito e tem como fundamentos:

Parágrafo único. Todo o poder emana do povo, que o exerce por meio de representantes eleitos ou diretamente, nos termos desta Constituição.

61 Art. 14. A soberania popular será exercida pelo sufrágio universal e pelo voto direto e secreto, com valor igual para todos, e, nos termos da lei, mediante:

62 GOMES, José Jairo. Direito Eleitoral. 5 ed. Belo Horizonte: Del Rey, 2010, pág. 37.

63 DALLARI, Dalmo de Abreu. Elementos de Teoria Geral do Estado. $29^{\circ}$ ed. São Paulo: Saraiva, 2010. Pág. 183.

64 DALLARI, Dalmo de Abreu. Elementos de Teoria Geral do Estado. $29^{\circ}$ ed. São Paulo: Saraiva, 2010, Pág. 183. 
A respeito da soberania popular Fávila Ribeiro preconiza que o exercício dessa somente ocorre quando da realização do sufrágio nacional ${ }^{65}$. Assim também compreende Erick Wilson Pereira quando exprime "só existirá plenitude da soberania popular com a preservação da igualdade e da liberdade quando do exercício do sufrágio."66

Por ser requisito do Estado democrático e fundamento da Constituição Federal vigente a prática do sufrágio se mostra essencial a garantia da liberdade política presente no estado social. No Brasil o artigo 14 da Carta Magna utiliza as expressões sufrágio universal e voto para caracterizar como se dará o exercício da soberania popular.

Como sufrágio universal José Jairo Gomes explica ser "o direito de votar e de ser votado"67, garantindo que a soberania popular seja efetivada e o poder permaneça com o povo, por universal, entende-se que o Estado busca assegurar o direito de exercício do voto ao maior número de cidadãos ${ }^{68}$.

André Ramos Tavares preconiza que o sufrágio é característica dos Estados republicanos democrático, que o exercem por meio do voto, fundamentando a diferença entre voto e sufrágio ao citar Kelsen com a ideia do sufrágio ser a permissão ao voto. 69

No que tange ao voto, como exercício do sufrágio, José Jairo Gomes define-o como o ato de escolha dos representantes políticos pelo povo, tratando-se de um direito, porém é também um dever, pois o contrato social do estado democrático é mister a participação da população ${ }^{70}$.

No Brasil, o voto é direto, o que implica definir que o cidadão elege diretamente os governantes, sem interferências de outros. Ademais o voto também é secreto, no sentindo literal da palavra, pois o voto não pode ser revelado pela Justiça Eleitoral de forma a identificar o eleitor ${ }^{71}$.

65 RIBEIRO, Fávila. Direito Eleitoral. $4^{\circ}$ ed. Rio de Janeiro: Forense,1996. Pág. 347.

66 PEREIRA, Erick Wilson. Direito Eleitoral: interpretação e aplicação das normas constitucionaiseleitorais. São Paulo: Saraiva, 2010. Pág. 155.

67 GOMES, José Jairo. Direito Eleitoral. 5 ed. Belo Horizonte: Del Rey, 2010, pág.. 39

68 GOMES, José Jairo. Direito Eleitoral. 5 ed. Belo Horizonte: Del Rey, 2010, pág. 40

69 TAVARES, André Ramos. Curso de Direito Constitucional. 8 ed. São Paulo: Saraiva, 2010. Pág. 807

70 GOMES, José Jairo. Direito Eleitoral. 5 ed. Belo Horizonte: Del Rey, 2010, pág. 43

71 GOMES, José Jairo. Direito Eleitoral. 5 ed. Belo Horizonte: Del Rey, 2010, pág. 44 
O artigo 14 da Constituição Federal expressa ainda as formas do exercício pelo plebiscito, referendo e iniciativa popular, com execução regulamentada pela lei n 9.709 de 18 de novembro de 1998.

O plebiscito e o referendo são formas de participação direta do povo, detentor da soberania, sobre matérias relevantes à Nação, podendo ser de ordem constitucional, administrativa ou legislativa. A única diferença encontra-se no fato do plebiscito ocorrer antes do ato em questão, e o referendo ser realizado posterior de modo que a população somente aprova ou reprova a proposta ${ }^{72}$.

A convocação de um referendo ou plebiscito se dá por um decreto legislativo, quando proposto por no mínimo um terço dos componentes das Casas do Congresso Nacional. Quando a matéria em questão for um dos casos do $\S 3^{\circ}$ do artigo 18 da Constituição Federal _ incorporação, subdivisão ou desmembramento dos Estados _ a lei regulamenta que por existir o interesse direto da população ocorrerá então o plebiscito, bem como necessitará da aprovação do Congresso Nacional, via lei complementar.

Quando da convocação, deverá o presidente do Congresso Nacional comunicar a justiça eleitoral, para que esta possa realizar o procedimento pertinente às eleições com lisura e idoneidade, bem como garantir a maior participação dos cidadãos. A aprovação do plebiscito ou referendo se consolidará por maioria simples, com sua homologação pelo Tribunal Superior Eleitoral (TST), seguindo para o Congresso Nacional onde obedecerá aos tramites comum do regimento comum da casa.

No que tange à iniciativa popular, no artigo 13 e seguintes da lei 9.709/98, prevê que a população encaminhe a Câmara dos Deputados um projeto de lei, estabelecendo os requisitos de participação de no mínimo um por cento do eleitorado nacional, distribuídos por cinco Estados, e mínimo de três décimos por cento dos eleitores de cada um deles.

É evidente que na teoria, e nas belas palavras da Constituição e da legislação ordinária a soberania popular no Brasil constitucional é o direito máximo no Estado Democrático, porém o que se nota na realidade brasileira é uma tentativa de muitos

72 BRASIL. Tribunal Superior Eleitoral. Plebiscitos e referendos. Disponível em <http://www.tse.jus.br/eleicoes/plebiscitos-e-referendos>. Acesso em 02/2014; BRASIL, Lei n. 9.709, de 18 de novembro de 1998. Disponível em: <http://www.planalto.gov.br/ccivil_03/leis/l9709.htm>. Acesso em 02/2014. 
representantes políticos induzirem a população a aceitar os seus atos de forma inquestionável, sobrepondo seus interesses particulares ao interesse público.

A seguir serão demonstradas algumas formas, legitimas, de ação da população quando dos atos impróprios dos representantes políticos.

\subsection{Legitimidade de ação perante a ilegitimidade dos atos dos representantes políticos}

Os atos de improbidade administrativa dos políticos no Brasil destacam-se a cada dia mais na imprensa e nas redes sociais, no ano de 2013 muitos cidadãos foram às ruas com cartazes, faixas e vontade de lembrar aos governantes que "Todo poder emana do povo" (art. $1^{\circ}$, parágrafo único da Constituição), diante dessa realidade e após conceituar a soberania e seu exercício este documento demonstrará agora as formas legítimas de reação da população para com os políticos que se desvirtuam da sua função maior de representar a população, Raul Pilla ao ser mencionado por Brossard afirma que "governo irresponsável, embora originário de eleição popular, pode ser tudo menos democrático"73.

Uma das formas de ação legitima e legal para o comportamento indevido dos políticos é a propositura de ação de impeachment, prevista na legislação brasileira pela Lei $N^{\circ} 1.079$ de 1950, que define os crimes de responsabilidade e descreve a forma do processo, disposto na Constituição de 1988 nos artigos 85 e 86, que estabelecem a necessidade de lei ordinária para processar e julgar crimes de responsabilidade.

Aliada a lei dos crimes de responsabilidade, o ordenamento jurídico brasileiro prevê ainda a Lei $\mathrm{n}^{\circ} 8.429$ de 1992, conhecida como a lei da improbidade administrativa, que institui sanções para feitos como enriquecimento ilícito, atos que atentem contra os princípios da administração pública, bem como os atos que violem o erário público. Ademais a lei enquadra que qualquer agente público, seja servidor ou não, estará sujeito a imputação legal, sem afastar a sujeição dos responsáveis no âmbito penal se assim a legislação prevê.

A acusação de improbidade administrativa pode ser representada por qualquer pessoa, identificando-se o representante, descrição do fato e indicação de quem o cometeu, bem como indicador de provas do ato improbado. O tema é vasto,

73 PILLA apud BROSSARD, Paulo. O impeachment. 3 ed. São Paulo: Saraiva, 1992. Pág. 3 
genérico e consagra muitas discussões, porém este documento se aterá ao exercício regular da soberania popular pelo impeachment.

Historicamente o impeachment surgiu na Inglaterra onde a Câmara dos Comuns apresentava as acusações contra os Ministros do Rei, que eram julgados pela Câmara dos Lordes $^{74}$ com liberdade de aplicação de penas ao político e ao homem ${ }^{75}$.

Porém segundo Brossard o instituto na Inglaterra passou por momentos de inconstância e até mesmo de letargia, quando da era do bill of attainder ${ }^{76}$ propiciando então o ressurgir do impeachment com vigor ${ }^{77}$. Fora a ele recorrido quando dos casos de ofensa à Constituição, mesmo que as previsões legais não definissem o crime em especifico, mas de forma geral, permanecendo aos Lordes a cominação da pena.

O impeachment inglês apresentava originariamente natureza penal de modo a punir o indivíduo que fosse reclamado pelo clamor público, com características de natureza política, buscando afastar aquele que ofende o Estado. Com a volta do uso do impeachment este passou a apresentar natureza apenas política, com punições de perdas e destituições de cargos e direitos políticos. ${ }^{78}$

Nos Estados Unidos da América o impeachment foi racionalizado, de modo que desde sua origem cunhou apenas características políticas, doutrinadores afirmam que isso ocorreu por ser notável a experiência inglesa. Portanto nos Estados Unidos o instituto atingia apenas a autoridade, de modo a afastá-lo do cargo, podendo a justiça julgar os crimes afastada a natureza política do processo ${ }^{79}$.

Ao analisar o processo e julgamento dos crimes de responsabilidade no Brasil é notória a semelhança com o impeachment americano, não restando dúvidas da inspiração brasileira. Paulo Brossard descreve o impeachment no Brasil:

74 FAVER, Marcus. Considerações sobre origem e natureza do impeachment. Disponível em < http://www.tjrj.jus.br/c/document_library/get_file?uuid=b4d02b0b-cf66-47e8-81355271575 f09db\&groupld=10136>. Acesso em 03/2014.

75 BROSSARD, Paulo. O impeachment. $3^{\circ}$ ed. São Paulo: Saraiva, 1992, pág. 22.

76 As pessoas eram condenadas por crimes sem que houvesse o processo, sendo apenas imputadas as penas.

77 BROSSARD, Paulo. O impeachment. $3^{\circ}$ ed. São Paulo: Saraiva, 1992, pág. 27.

78 GÓES, Mauricio Silva de. Impeachment Inglês. Disponível em < http://www.fmr.edu.br/npi/046.pdf>. Acesso em 03/2014.

79 STORY, Joseph apud FAVER, Marcus. Considerações sobre origem e natureza do impeachment. Disponivel em <http://www.tjrij.jus.br/c/document_library/get_file?uuid=b4d02b0b-cf66-47e8-81355271575f09db\&groupld=10136>. Acesso em 03/2014. 
Segundo a Constituição de 1988, o impeachment do Presidente da República, por crimes de responsabilidade, se desenrola no Senado, desde sua instauração até o julgamento final; mas o Senado não pode instaurá-lo, senão depois de autorizado, pelo voto de dois terços da Câmara dos Deputados; sem a autorização não pode encetá-lo, e uma vez autorizado não pode deixar de instaurá-lo; instaurado o processo, o Presidente é suspenso do cargo, que passa a ser exercido por seu substituto legal; se em cento e oitenta dias, porém, a decisão definitiva não houver sido prolatada, o processo continua regularmente, mas a autoridade afastada retoma o exercício de suas funções, até o julgamento, para ser absolvida ou condenada, se nesse sentido for o voto de dois terços do Senado, cuja decisão é irrecorrível; uma vez condenado, fica inabilitado para exercer qualquer função pública por oito anos; a sanção política aplicada pelo Senado não exclui outras sanções, aplicáveis pelo Poder Judiciário, nos termos da lei. ${ }^{80}$

A descrição de Brossard se atém aos escritos da legislação, de forma objetiva, demonstrando que apesar de nome distinto daquele americano o Brasil adotou o impeachment com natureza apenas política, isso não significa que os condenados não responderão por seus atos na justiça, se assim for previsto ocorrerá à atuação do poder judiciário.

No Brasil conforme prevê a Lei $n^{\circ} 1.079$ de 1950, qualquer pessoa pode propor a ação de impeachment, cabendo à Câmara dos Deputados aceitar ou não a denúncia.

A possibilidade de aplicação do impeachment para Paulo de Figueiredo é algo essencial ao regime presidencialista, de modo a banir qualquer golpe, atentado ou irresponsabilidade dos representantes do povo contra a soberania popular e o Estado. ${ }^{81}$

Ao brasileiro além do instituto do impeachment o exercício de sua soberania pode e deve ser exercido de modo menos complexo, e podemos pensar menos gravoso e prejudicial ao país, pois ocorre antes mesmo da permissão de acesso ao poder por aqueles maus representantes, remeta-se então a escolha popular.

A escolha dos governantes deve ser algo racional, de modo que os cidadãos pesquisem de fato a vida política de cada candidato, permitindo o acesso às informações que possam transparecer a conduta pregressa daqueles que almejam

80 BROSSARD, Paulo. O impeachment. 3 ed. São Paulo: Saraiva, 1992. Pág. 7

81 FIGUEIREDO, Paulo de. Impeachment sua necessidade no regime presidencial. Revista de Informação Legislativa. Junho, 1965. $\quad$ Pág $1 . \quad$ Disponível em: <http://www2.senado.gov.br/bdsf/item/id/180677>. Acesso em 03/2014. 
representar o povo, diminuindo o risco de entregar o poder a políticos que sobreponham seus interesses aos do povo.

Neste capítulo fora demonstrado o conceito de soberania popular, esta exercida em uma democracia, no Brasil o tipo de democracia característico é o representativo, conceituando no próximo capitulo do presente documento, inserindo informações relevantes ao ponto cerne deste trabalho.

\section{DEMOCRACIA REPRESENTATIVA - VIABILIZAÇÃO DA SOBERANIA POPULAR E ANOMALIAS}

\subsection{DEMOCRACIA: CONCEITO E TIPOS}

A participação do povo no poder do Estado caracteriza a democracia. Originada na Grécia, é apontada como poder do povo. Diante da evolução histórica política e social da humanidade, acrescentaram-se ao termo democracia pressupostos e ideais a sua essência, que revelam o desenvolvimento sócio político das nações ${ }^{82}$.

A forma democrática de ser Estado ainda é característica marcante nos povos ocidentais, restando inclusive - a democracia - haver sido inserida ao rol dos direitos humanos, no artigo XXI da Declaração Universal dos Direitos do Homem de 1948, e no artigo 25 do Pacto Internacional sobre Direitos Civis e Políticos de $1966^{83}$.

Kelsen atribui à democracia a ideia de liberdade negativa, alegando que está em seu sentido estrito somente seria possível em um estado natural. No estado social a libertação passa a ser política, regendo-se por uma ordem social que na democracia é formada pela vontade da maioria, a autonomia está no fato da ordem social ser elaborada pelos indivíduos da sociedade, atribuindo-lhes autonomia de ser Estado e assim garantir o exercício da liberdade ${ }^{84}$.

A saber, José Afonso da Silva, imputa ao termo democracia uma relevante carga histórica em seu conceito, com a característica mestre de ser um regime político exercido, direta ou indiretamente, pelo povo, demonstrando que a razão de

82 O termo "nações" aqui usado no sentido de Estado soberano.

83 GOMES, José Jairo. Direito Eleitoral. 5 ed. Belo Horizonte: Del Rey, 2010. Pág. 29

84 KELSEN, Hans. Teoria Geral do Direito e do Estado. 3 ed. São Paulo: Martins Fontes, 1998. Págs. 407 e 408. 
ser Estado democrático está na soberania popular ${ }^{85}$. Lincoln fora bem citado pelo autor conceituando que a democracia "é governo do povo, pelo povo e para o povo"86, externando em breves palavras um conceito amplo e correto.

$\mathrm{Na}$ doutrina constata-se uma subdivisão da democracia, em direta, indireta e a semidireta ${ }^{87}$.

A democracia direta ocorre quando o poder é exercido diretamente pelo povo, onde todas as questões do Estado são submetidas ao crivo dos cidadãos. Originada na Grécia, o direito de participar da vida política das cidades era concedido somente aos cidadãos, sendo estes os homens livres, que se reuniam na Àgora ${ }^{88}$, e então deliberavam sobre questões legislativas, executivas e judiciais ${ }^{89}$.

$\mathrm{Na}$ forma direta a participação efetiva dos cidadãos nos três poderes exige dedicação, o que na Grécia clássica era possível visto que os homens livres não se preocupavam com outras questões se não os referentes ao Estado, pois os escravos eram encarregados das demais necessidades da sociedade ${ }^{90}$.

Para Bobbio a democracia direta é a participação dos cidadãos no poder sem intermediários ${ }^{91}$, Paulo Sérgio Novais de Macedo acrescenta "refere-se ao sistema político em que os cidadãos decidem, de forma direta, cada assunto, por meio do voto"92.

Kelsen leciona que a democracia direta é exercida em assembleia popular, sendo viável em comunidades ou pequenas cidades, que não apresentem problemas complexos em sua formação sócio política ${ }^{93}$.

85 SILVA, José Afonso da Silva. Curso de Direito Constitucional Positivo. 36 ed. São Paulo: Malheiros editores, 2013. Pág. 128

86 LINCOLN apud SILVA, José Afonso da Silva. Curso de Direito Constitucional Positivo. $36^{\circ}$ ed. São Paulo: Malheiros editores, 2013, pág 128.

87 SILVA, José Afonso da Silva. Curso de Direito Constitucional Positivo. $36^{\circ}$ ed. São Paulo: Malheiros editores, 2013, Pág. 128.

88 Espécie de praça pública destinada a reuniões para discussões da vida pública.

89 BONAVIDES, Paulo. Ciência Política. $10^{\circ}$ ed. São Paulo: Malheiros, 2001. Pág. 268.

90 BONAVIDES, Paulo. Ciência Política. 10 ed. São Paulo: Malheiros, 2001. Pág. 268.

91 BOBBIO apud LYRA, Rubens Pinto. Teorias clássicas sobre a democracia direta e a experiência brasileira. Revista de Informação Legislativa, v. 35, n. 140, p. 11-16, out./dez. de 1998. Disponível em: < http://www2.senado.gov.br/bdsf/item/id/413>. Acesso em 03/2014.

92 MACEDO, Paulo Sérgio Novais de. Democracia Participativa na Constituição Brasileira. Revista de informação legislativa, v.45, $\mathrm{n}^{\circ}$ 178, p. 181-193, abr./jun. de 2008 . Disponível em: $<$ http://www2.senado.gov.br/bdsf/item/id/176529>. Acesso em 04/2014.

93 KELSEN, Hans. Teoria Geral do Direito e do Estado. 3 ed. São Paulo: Martins Fontes, 1998. Pág. 412. 
A segunda forma de democracia é a indireta, ou representativa, na qual é reconhecido que o poder soberano é do povo, porém o governo é exercido por representantes eleitos periodicamente pelos cidadãos ${ }^{94}$.

A democracia representativa implica na existência de diversos institutos da representação, como o sufrágio universal, as eleições, os partidos políticos e mandatos eletivos, o ápice da participação do povo nesta forma democrática se dá nas eleições, quando ocorre então a escolha e reconhecimento dos representantes do povo. ${ }^{95}$

José Afonso da Silva leciona que a forma de representação ocorre em face da inviabilidade do cidadão gerir diretamente todos os assuntos do Estado, por fatores que iniciam da extensão territorial a complexidade dos assuntos sociais, e de forma representativa o povo permanece detentor do poder outorgando o poder aos representantes por períodos determinados ${ }^{96}$.

A democracia representativa perfaz o caminho em que nem todo cidadão é político, ou seja, nem todos se interessam, ou mesmo estão aptos a decidir as questões do Estado. No Estado, decisões tomadas pelo clamor público podem ensejar problemas maiores, ou mesmo ser o povo impressionado por figuras carismáticas que o induzirão a acreditar em falsas promessas. ${ }^{97}$

$\mathrm{Na}$ teoria da forma representativa da democracia os representantes do povo são pessoas que detenham os conhecimentos necessários a conduzir a administração do Estado ${ }^{98}$, e que segundo Kelsen deve haver uma garantia jurídica de que o representante terá suas decisões de acordo com a vontade do povo ${ }^{99}$.

No Brasil constata-se que a irresponsabilidade de tantos representantes e a permanência destes no poder _ por encontrarem nos aliados formas de mascarar

94 SILVA, José Afonso da. Curso de Direito Constitucional Positivo. 36 ed. São Paulo: Malheiros editores, 2013. Pág. 138.

95 MACEDO, Paulo Sérgio Novais de. Democracia Participativa na Constituição Brasileira. Revista de informação legislativa, v.45, $\mathrm{n}^{\circ}$ 178, p. 181-193, abr./jun. de 2008 . Disponível em: <http://www2.senado.gov.br/bdsf/item/id/176529>. Acesso em 04/2014.

96 SILVA, José Afonso da. Curso de Direito Constitucional Positivo. $36^{\circ}$ ed. São Paulo: Malheiros editores, 2013, pág. 138.

97 MACEDO, Paulo Sérgio Novais de. Democracia Participativa na Constituição Brasileira. Revista de informação legislativa, v.45, $\mathrm{n}^{\circ}$ 178, p. 181-193, abr./jun. de 2008. Disponível em: <http://www2.senado.gov.br/bdsf/item/id/176529>. Acesso em 04/2014.

98 MACEDO, Paulo Sérgio Novais de. Democracia Participativa na Constituição Brasileira. Revista de informação legislativa, v.45, $\mathrm{n}^{\circ}$ 178, p. 181-193, abr./jun. de 2008 . Disponível em: <http://www2.senado.gov.br/bdsf/item/id/176529>. Acesso em 04/2014.

99 KELSEN. Hans. Teoria Geral do Direito e do Estado. 3 ed. São Paulo: Martins Fontes, 1998. pág. 414. 
uma mudança dos representantes, fazendo chegar ao cargo familiares _ ensejou a participação de figuras hilárias no cenário político nacional, seja de semianalfabeto a funkeiras, e até servidores fantasma, demonstrando assim a não tecnicidade de quem detém o poder.

No que tange a democracia semidireta, denominada por alguns doutrinadores também de participativa ${ }^{100}$, reúnem-se elementos da democracia representativa, e somam-se alguns institutos da democracia direta, que efetivam a participação do povo em determinadas decisões em assunto relevantes do Estado ${ }^{101}$.

O Diário do Senado Federal define a democracia semidireta como a democracia representativa coexistindo com elementos da direta. Trata-se esta democracia de um misto entre a forma direta e a indireta, assim o diz Bonavides, ressaltando que neste regime democrático é possível ao governo criar instituições que teriam a participação do povo e dos seus representantes, os governantes. ${ }^{102}$

No Brasil, a Constituição Federal prevê em seu artigo $1^{\circ}$ que o poder do povo será exercido por meio de representantes ou diretamente, fazendo-se entender a presença de elementos da democracia representativa bem como da democracia direta ${ }^{103}$.

José Afonso da Silva instrui que o Brasil, segundo a Constituição Federal, combinou elementos da democracia direta e indireta, regidos pelos artigos 14 a 17 da referida Carta Magna. O renomado autor explica que a democracia brasileira não é participativa, em seu sentido atual de participação efetiva dos cidadãos, afirmando que "a eleição consubstancia o princípio representativo, segundo o qual o eleito pratica atos em nome do povo"104.

Cabendo ao artigo 14 da Carta Magna inserir as formas de exercício da soberania popular, ou seja, as formas de participação direta do cidadão na

100 Discute-se a aceitação do termo participativa como sinônima de semidireta, pois a semidireta seria então uma fusão de institutos de dois tipos democráticos - a direta e indireta -, enquanto que o conceito de democracia participativa vai além, abrangendo os institutos da democracia semidireta, e incluindo a participação dos indivíduos em todas as formas de legitimação do poder e atuação do povo. (MACEDO, Paulo Sérgio Novais de. Democracia Participativa na Constituição Brasileira. Revista de informação legislativa, v.45, n 178, p. 181-193, abr./jun. de 2008. Disponível em: <http://www2.senado.gov.br/bdsf/item/id/176529>. Acesso em 04/2014).

101 SILVA, José Afonso da Silva. Curso de Direito Constitucional Positivo. 36 ed. São Paulo: Malheiros editores, 2013. Pág. 138

102 BONAVIDES, Paulo. Ciência Política. 10 ed. São Paulo: Malheiros, 2001. Pág. 274 e 275.

103 Cf. art. $1^{\circ}$ Constituição da República Federativa do Brasil de 1988. Disponível em: < http://www.planalto.gov.br/ccivil 03/constituicao/constituicao.htm>. Acesso em 03/2014.

104 SILVA, José Afonso da Silva. Curso de Direito Constitucional Positivo. 36 ed. São Paulo: Malheiros editores, 2013. Pág. 143 
administração pública, tomando não apenas o voto como fundamento legal da democracia, mas também os meios constitucionais de referendo, plebiscito e iniciativa popular ${ }^{105}$, anteriormente descritos neste documento.

Apesar de devidamente reguladas as formas de participação direta do cidadão brasileiro, os institutos recebem diversas críticas dos mais renomados doutrinadores pelo pouco, ou não uso, destes pelos legisladores nacionais, diante deste cenário Paulo Bonavides expõe severa crítica a lei 9.709/98, por não constar nela todas as matérias que deveriam estar sujeitas a participação do povo, causando então "ofensa ao princípio da legitimidade"106.

\subsection{CRISE DE LEGITIMIDADE}

A legitimidade do poder concedida pelo povo aos representantes encontra fundamento na Constituição, desde seu preâmbulo, quando consta que o texto constitucional foi elaborado por representantes do povo ${ }^{107}$, e os indivíduos então reconhecem tal representatividade.

O conceito de legitimidade vem então justificar o poder, confundindo-se com legalidade por estar reconhecido na carta magna, mas para José Afonso da Silva o conceito de legalidade e legitimidade, no Brasil, não se confundem, atribuindo a legalidade não somente a obediência à forma da lei, mas respeito aos princípios contidos na Carta Política ${ }^{108}$. No que tange a legitimidade, Ricardo Duarte Junior, leciona que "a legitimidade é conferida quando a lei, e outras espécies normativas, estão de acordo com a norma fundamental" 109.

105 Cf. art. 14 Constituição da República Federativa do Brasil de 1988. Disponível em: < http://www.planalto.gov.br/ccivil_03/constituicao/constituicao.htm>. Acesso em 03/2014; MACEDO, Paulo Sérgio Novais de. Democracia Participativa na Constituição Brasileira. Revista de informação legislativa, v.45, $n^{\circ} 178$, p. 181-193, abr./jun. de 2008. Disponível em: < http://www2.senado.gov.br/bdsf/item/id/176529>. Acesso em 04/2014.

106 BONAVIDES, Paulo. Teoria Constitucional da Democracia Participativa. 2 ed. São Paulo: Malheiros, 2003. Pág. 108.

107 Cf. preâmbulo da Constituição da República Federativa do Brasil de 1988. Disponível em: < http://www.planalto.gov.br/ccivil_03/constituicao/constituicao.htm>. Acesso em 03/2014.

108 SILVA, José Afonso da. Curso de Direito Constitucional Positivo. 36 ed. São Paulo: Malheiros editores, 2013. Pág. 426.

109 DUARTE JUNIOR. Ricardo César Ferreira. Democracia Participativa e Regulação Econômica: Uma questão de legitimidade. Dissertação (Mestrado em Direito Constitucional), Universidade Federal do Rio Grande do Norte. Natal, 2013. 
José Alfredo de Oliveira Baracho afirma que "o poder do Estado é legítimo quando é aceito pelos destinatários das normas jurídicas ${ }^{110 ", ~ a ~ C o n s t i t u i c ̧ a ̃ o ~ F e d e r a l ~}$ rege a todos os indivíduos, sejam governados ou governantes.

Atribuindo à legitimidade a ideia de obediência ao poder, onde devem os cidadãos e os seus representantes ser regidos e reconhecerem poder da norma maior vigente, fazendo-se necessário que o Estado se mostre eficaz no cumprimento da lei e na exigência de se fazer cumprir ${ }^{111}$.

Danielle S. Dias, ilustra que o poder político democrático legitimado deve manifestar não somente a letra da lei, mas deve incluir os valores da comunidade em seus atos, vez que o Estado representa o maior poder legitimado, pois os governados demonstram o respeito, ainda que de forma institucional ${ }^{112}$.

O Magno Texto Republicano insere a participação direta do povo na democracia, porém as críticas ao regime democrático no Brasil encontram-se aí centrado, visto que a forma representativa se sobressai a participação direta dos indivíduos, o que se nota é uma manobra dos representantes políticos em afastar o cidadão dos assuntos do Estado.

Bonavides doutrina a respeito da evolução constitucional do Brasil asseverando que a Constituição de 1988 é a melhor das Constituições brasileiras, comentando ainda que "onde ela mais avança é onde o Governo mais intenta retrogradá-la"113.

A primeira constituição do Brasil datada de 1824 estabelecia quatro poderes, sendo o executivo, o legislativo, o judiciário e o poder moderador, sendo o primeiro e o ultimo atribuídos a uma só pessoa, ao Imperador ${ }^{114}$.

A constituição de 1824 teve sua queda em 1889, com a criação da República, e em 1891 foi promulgada a primeira Constituição da República dos Estados Unidos

110 BARACHO, José Alfredo de Oliveira. Legitimidade do Poder. Revista de informação legislativa, v.22, $\mathrm{n}^{\circ} \quad 86, \quad$ p. 13-28, abr./jun. de 1985. Disponível em < http://www2.senado.gov.br/bdsf/item/id/181611>. Acesso em 04/2014.

111 BARACHO, José Alfredo de Oliveira. Legitimidade do Poder. Revista de informação legislativa, v.22, $\mathrm{n}^{\circ} \quad 86, \quad$ p. 13-28, abr./jun. de 1985. Disponível em < http://www2.senado.gov.br/bdsf/item/id/181611>. Acesso em 04/2014, Pág. 26

112 DIAS, Danielle S. Soberania: a legitimidade do poder estatal e os novos rumos democráticos. Revista de informação legislativa, v. 48, n. 192, p. 55-66, out./dez. 2011. Disponível em: <http://www2.senado.gov.br/bdsf/item/id/242929>. Acesso em 04/2014.

113 BONAVIDES, Paulo. Teoria Constitucional da Democracia Participativa. $2^{\circ}$ ed. São Paulo: Malheiros, 2003. Pág. 204.

114 BONAVIDES, Paulo. Teoria Constitucional da Democracia Participativa. $2^{\circ}$ ed. São Paulo: Malheiros, 2003, pág. 197. 
do Brasil, instalando a forma federativa de ser Estado, e a tripartição de poderes, sob as críticas de Bonavides a alteração se deu tão somente na legislação, demonstrando que os governantes não concebiam a atual forma ${ }^{115}$.

Nos estados os governos fundavam-se pelo coronelismo, período o qual os então coronéis obedeciam e se faziam obedecerem às suas próprias leis pelo uso da força, de tal forma que os governadores encontravam neles a oportunidade de ser eleito, pois a população votava conforme o coronel ordenasse ${ }^{116}$.

O fim da primeira república se deu com a Revolução de 1930, ascendendo Getúlio Vargas no poder, uma nova assembleia constituinte fora convocada e em 1934 o país tem novo texto constitucional, destacando-se a intervenção do governo federal nos estados, ampliando a competência da União, ademais acresceu matéria de ordem de direitos fundamentais ${ }^{117}$.

Em 1937 Getúlio Vargas declara nova carta política, centralizando o poder, extinguindo o Congresso, vinculada ao autoritarismo, sob a justificativa de manutenção da ordem social ${ }^{118}$, fora uma época de decretos leis sancionadas e aplicadas pelo próprio presidente, ou seja, uma época de ditadura, chegando ao fim em $1945^{119}$.

Fim do Estado Novo ${ }^{120}$, o país buscou a redemocratização, instituído então a forma parlamentar, convocaram-se novas eleições para presidente, e em 1946 uma nova constituinte promulgou nova Carta Política, baseada em modelos fracassados anterior restou no insucesso da sua aplicação. Um período de incerteza quanto ao

115 BONAVIDES, Paulo. Teoria Constitucional da Democracia Participativa. $2^{\circ}$ ed. São Paulo: Malheiros, 2003, pág. 199.

116 SILVA, José Afonso da. Curso de Direito Constitucional Positivo. 36 ed. São Paulo: Malheiros editores, 2013. Pág. 82.

117 Cf. SILVA, José Afonso da. Curso de Direito Constitucional Positivo. 36 ed. São Paulo: Malheiros editores, 2013. Pág. 83 e 84. Cf. TAVARES, André Ramos. Curso de Direito Constitucional. 8 ed. São Paulo: Saraiva, 2010.

118 BRASIL. Presidência da República. Ex-presidentes. Disponível em: $<$ http://www.biblioteca.presidencia.gov.br/ex-presidentes/getulio-vargas/biografia-periodopresidencial>. Acesso em 04/2014.

119 SILVA, José Afonso da. Curso de Direito Constitucional Positivo. 36 ed. São Paulo: Malheiros, 2013. Pág. 85

120 Denominação atribuída a nova ordem nacional, quando Getúlio Vargas institui o golpe de Estado de 1937. SILVA, José Afonso da. Curso de Direito Constitucional Positivo. 36 ed. São Paulo: Malheiros, 2013. pág. 84. 
chefe do poder executivo, com diversas trocas, acompanhada ao final de uma reação militar que ensejou em nova ditadura ${ }^{121}$.

A ditadura militar governou sob Atos institucionais, culminando em nova constituição em 1967, com texto que centralizava o poder na União e na figura do Presidente da República e suspendeu direitos e garantias individuais, os Atos institucionais não cessaram e em 1969 o poder retorna aos militares, uma nova ditadura assombrava o país, destacando o Ato Institucional 5 como o mais autoritário. ${ }^{122}$

Em 1982 as forças democráticas foram ganhando força e contagiando a população, que elegeram Tancredo Neves sob as promessas de um novo país, novos direitos, com o falecimento do presidente eleito toma posse o Vice-presidente, José Sarney, que convocou o Congresso para nova Assembleia constituinte, resultando este na Constituição Federal de $1988^{123}$.

Apesar de tantas constituições em poucas delas foram registrados avanços nos direitos fundamentais individuais, os acessos à educação e formação cultural permaneciam restritos a elite, as oposições governamentais dos períodos preocupavam-se mais em tomar o poder do que com as condições reais dos indivíduos, a Constituição de 1988 é a versão mais cidadã da história política nacional, efetiva a participação do povo, visa garantir direitos fundamentais de forma igualitária a todos.

A democracia representativa, então adotada na ordem constitucional nacional, define a participação do cidadão nas eleições, porém as decisões no que tange aos problemas sociais permanecem com os poderosos, sob o fundamento do bem-estar social. Os governantes entregam a população serviços básicos precários, e agrega a população carente programas sociais que ao invés de formar o cidadão tem mantido a alienação político - social.

A crise de legitimidade instaura-se no ser Estado institucional, quando o poder Executivo reveste o ordenamento sócio jurídico de medidas provisórias, medidas

121 SILVA, José Afonso da. Curso de Direito Constitucional Positivo. 36 ed. São Paulo: Malheiros, 2013. Pág. 85. TAVARES, André Ramos. Curso de Direito Constitucional. 8 ed. São Paulo: Saraiva, 2010.

122 SILVA, José Afonso da. Curso de Direito Constitucional Positivo. 36 ed. São Paulo: Malheiros, 2013. Pág. 89.

123 SILVA, José Afonso da. Curso de Direito Constitucional Positivo. 36 ed. São Paulo: Malheiros editores, 2013. Pág. 91. 
estas aprovadas pelo Congresso Nacional, sem considerar as necessidades e interesses dos cidadãos.

As medidas provisórias sujeitam os indivíduos as vontades e interesses da elite governante, afastando a população da democratização e do exercício efetivo da cidadania.

O Estado toma para si todas as decisões, disfarçando-se de assistencialista, quando na verdade retira do povo a oportunidade de decidir sobre as questões do seu meio, pois os problemas sociais cotidianos enfrentados pela maioria da população não correspondem à realidade daqueles que compõem a cúpula dos representantes.

Roberto Amaral recorre ao exemplo dos Estados Unidos de não ter o voto obrigatório, percebendo que a participação do cidadão é pequena, em razão do indivíduo perceber o manuseio pelos partidos, justificando recorrer ao exemplo americano por ser este exemplo de democracia representativa visado pela cúpula política nacional. Destacando a presença de negociações entres partidos e políticos, de modo a sobreporem suas vontades em detrimento da soberania popular, "bem aprendidas pela política brasileira"124.

Nesse sentido os governantes têm perdido a confiança de parcela da população, esta corresponde aqueles que têm acesso à informação, e que de alguma forma se interessam pelo Estado social e sua função de promover o bemestar social.

O Estado não busca formar cidadãos, porém os indivíduos de uma forma ou de outra, lentamente ou não, tem buscado pensar no porquê de tantas notícias de desvios de verbas públicas, questiona o destino real de tantos impostos e taxas quando se aumenta o valor da passagem do transporte público. A crise de constitucionalidade não está na relação do indivíduo em identificar o seu papel como cidadão, mas sim no que tange aos governantes de perceberem que a atuação deles é de representantes do povo.

\subsection{ANOMALIAS DA DEMOCRACIA REPRESENTATIVA NACIONAL}

124 AMARAL, Roberto. A democracia representativa está morta: viva a democracia participativa! Direito constitucional: estudos em homenagem a Paulo Bonavides | Revista de informação legislativa, v. $38, \quad$ n. 151 , p. 29-65, jul./set. de 2001. Disponível em: <http://www2.senado.gov.br/bdsf/item/id/699>. Acesso em 04/2014. 


\subsubsection{Garantias constitucionais dos parlamentares - institutos anômalos}

Com a justificativa de garantir a independência do Congresso Nacional, ou seja, impedir a interferência dos outros poderes perante o Legislativo, a Constituição definiu prerrogativas aos parlamentares sendo estas hoje subdividas pela doutrina em inviolabilidade, imunidade, foro privilegiado, isenção do serviço militar, limitação ao dever de testemunhar ${ }^{125}$.

A respeito da inviolabilidade e imunidade, encontra-se a primeira prevista no caput do artigo 53 e a segunda no $\S 3^{\circ}$ do referido artigo, da Constituição Federal de 1988.

Sinônimo de imunidade material é a prerrogativa inviolabilidade, na qual se exclui o crime, ou seja, "afasta a incidência da norma penal incriminadora da conduta dos congressistas"126, garantindo a liberdade de expressão dos parlamentares ${ }^{127}$.

Os crimes devem ser derivados em face das opiniões, palavras e votos dos parlamentares, estejam em função ou não do cargo, justifica André Ramos Tavares sob o objetivo de "garantir a independência"128. A Carta Magna estende a inviolabilidade não somente aos senadores e deputados federais, mas também aos deputados estaduais conforme seu artigo $27, \S 1^{\circ}$ e aos vereadores, pelo artigo 29 , VIII, estes últimos dentro dos limites territoriais do seu município.

No que tange a imunidade formal, ou imunidade, José Afonso da Silva leciona que se trata de prerrogativa que "impede o processo"129, nesse sentido André Ramos Tavares aponta que anterior a Emenda Constitucional n³5/2001 o Supremo Tribunal Federal(STF) não prosseguia com o processo sem o consentimento da Casa do parlamentar, após a supracitada emenda "para que o processo seja

125 SILVA, José Afonso da. Curso de Direito Constitucional Positivo. 36 ed. São Paulo: Malheiros editores, 2013. Pág. 537.

126 TAVARES, André Ramos. Curso de direito constitucional. 8. ed. São Paulo: Saraiva, 2010. Pág 1240.

127 BRITO, Maria Orlange. Imunidade Parlamentar no Brasil antes e depois da Emenda Constitucional $n^{\circ} 35$, de 2001. Revista de informação legislativa, v. 44, n. 173, p. 239-254, jan./mar. 2007 Disponível em: < http://www2.senado.gov.br/bdsf/item/id/141291>. Acesso em 04/2014.

128 BRITO, Maria Orlange. Imunidade Parlamentar no Brasil antes e depois da Emenda Constitucional $n^{\circ} 35$, de 2001. Revista de informação legislativa, v. 44, n. 173, p. 239-254, jan./mar. 2007 Disponível em: < http://www2.senado.gov.br/bdsf/item/id/141291>. Acesso em 04/2014.

129 SILVA, José Afonso da. Curso de Direito Constitucional Positivo. 36 ed. São Paulo: Malheiros editores, 2013. Pág. 537. 
suspenso, há que obter manifestação expressa da Casa respectiva do parlamentar processado perante o Supremo Tribunal Federal"130.

A imunidade também impede a prisão do congressista, ressalvados os casos de flagrante dos crimes inafiançáveis, quando a Câmara respectiva deverá ser comunicada em 24 horas para deliberar sobre a prisão ${ }^{131}$.

O pitoresco instituto lançado na constituição tem a defesa fundamentada de que a proteção é direcionada ao Congresso e não ao representante político ${ }^{132}$ sob o argumento do livre exercício e defesa da democracia.

Ademais sobre prerrogativas parlamentares contem a Magna Carta o foro privilegiado aos membros do Congresso Nacional, trata-se de privilégio concedido aos congressistas de serem julgados pelo STF quando do processo e julgamento de infrações penais comuns em exercício do cargo.

De forma que deputados e senadores não são sujeitos a instância comum, mas tão somente ao STF. As duras críticas ao foro privilegiado encontram-se refugadas na ineficiência do sistema, pois o Supremo Tribunal hoje recebe demandas recursais diárias, atrasando então o julgamento de processos criminais originários no Supremo Tribunal.

O serviço militar se mostra incompatível com o exercício de mandato eletivo, desta forma o artigo $53, \S 7^{\circ}$ da Constituição Federal imuniza o congressista da prestação do serviço militar obrigatório a todos.

Caso seja da vontade do parlamentar servir as forças armadas deverá então renunciar ao mandato, possibilitando a incorporação somente com a licença da Casa a que pertença ${ }^{133}$.

A respeito da limitação ao dever de testemunhar indica tal prerrogativa a despeito do $\S 6^{\circ}$, do artigo 53 da Constituição que Deputados e Senadores não poderão ser intimados a depor em juízo, devendo então ser convidados pelo juízo.

130 TAVARES, André Ramos. Curso de Direito Constitucional. 8 ed. São Paulo: Saraiva, 2010. Pág. 1241.

131 SILVA, José A. da. Curso de Direito Constitucional Positivo. 36 ed. São Paulo: Malheiros editores. Pág. 538. Cf. art. 53, $\S 2^{\circ}$ da Brasil. Constituição da República Federativa do Brasil de 1988. Disponivel em: < http://www.planalto.gov.br/ccivil_03/constituicao/constituicao.htm>. Acesso em $04 / 2014$.

132 BRITO, Maria Orlange. Imunidade Parlamentar no Brasil antes e depois da Emenda Constitucional $n^{\circ} 35$, de 2001. Revista de informação legislativa, v. 44, n. 173, p. 239-254, jan./mar. 2007. Disponível em: <http://www2.senado.gov.br/bdsf/item/id/141291>. Acesso em 04/2014.

133 TAVARES, André Ramos. Curso de Direito Constitucional. 8 ed. São Paulo: Saraiva, 2010. Pág. 1242. 
Fala-se ainda da liberdade do congressista em escolher o dia e horário a prestar seu depoimento, não lhe sendo obrigado prestar testemunho "sobre informações recebidas ou prestadas em razão do exercício do mandato"134.

\subsubsection{Decisões constitucionais ou vontade política dos representantes?}

Sob impacto e influência dos meios de comunicação os partidos políticos se revezam no poder, nesse sentido Paulo Bonavides descreve a que a mídia usa do seu alcance para:

Degradar a vontade do popular, subtrair-lhe a eficácia de seu título de soberania, coagir a sociedade e o povo, inocular venenos sutis na consciência do cidadão, construir falsas lideranças com propaganda enganosa e ambígua, reprimir e sabotar com a indiferença e o silêncio dos meios de divulgação, tornados inacessíveis, a voz dos dissidentes e seu diálogo com a sociedade, manipular, sem limites e sem escrúpulos, a informação, numa aliança com o poder que transcende as raias da ética e tolher, enfim, a criação de uma opinião pública, livre e legítima, consciente e oxigenada pelos valores da justiça e liberdade ${ }^{135}$.

O que se nota, principalmente das grandes redes de tv, é o intuito mascarado em manter no poder o que já estão.

As formas de participação direta dos cidadãos são maculadas pelo Congresso nacional todos os dias, as pautas de votações não correspondem as expectativas da população, projetos de leis sobre assuntos de interesse da sociedade são engavetados, medidas provisórias legislam o ordenamento jurídico conforme a vontade do poder executivo.

\section{DAS CONSIDERAÇÕES FINAIS}

A sociedade desde os seus primórdios de vivência em grupo concebeu a ideia de liderança, de modo a atribuir poder a uma pessoa ou instituição, a evolução social concebeu então a ideia de Estado, como ente detentor de elementos constitutivos, sendo eles soberania, território, povo e finalidade.

134 SILVA, José A. da. Curso de Direito Constitucional Positivo. 36 ed. São Paulo: Malheiros editores. Pág. 538.

135 BONAVIDES, Paulo. Teoria Constitucional da Democracia Participativa.2 ed. São Paulo: Malheiros, 2003. Pág. 64. 
A soberania toma vestes de maior importância, pois seu reconhecimento perante outros Estados compõe a ordem jurídica de um novo país, o Estado torna inerente a si obrigações para com o povo, de modo a manter a segurança e ordem no território e suas extensões, elabora-se então um documento de força maior perante todos os indivíduos inseridos no território, a Constituição.

O texto constitucional nem sempre teve reconhecida sua força, pois as constituições imperiais não atendiam os anseios da sociedade, com as ideias iluministas de liberdade, igualdade e fraternidade espalhando-se pelos povos, os indivíduos ansiaram e lutaram por tomarem o poder e tornarem-se os detentores da soberania popular.

O crescimento demográfico dos Estados possibilitou o surgimento de novas formas de regimes governistas, entre eles o republicano, conceituado como governo de mais de uma pessoa, sendo subdivido em aristocracia ou democracia.

No Brasil o regime republicano democrático elege como forma de exercício da soberania o sufrágio e o voto, exercidos por meio de plesbicito, referendo e iniciativa popular. As inobservâncias disfarçadas pelos representantes políticos podem ensejar ações pelos representados, como o processo de impeachment ou a incidência na lei de improbidade administrativa.

Ambos somente são aplicáveis quando se tratar de figuras que componham a administração pública, em exercício de cargo ou função pública.

Após o exercício da soberania popular conceituou-se neste documento a democracia representativa, hoje vivenciada inteiramente no cenário político nacional, embora a Constituição Federal assegure que a soberania popular seja exercida direta e indiretamente.

Identificando, ao final, aberrações permitidas pela Carta Política, principalmente no Congresso Nacional, em tese o poder que mais representa o povo se mostra o mais omisso e letárgico em seu exercício, recebendo ordens do chefe do poder executivo.

Tendo em vista toda leitura e ampla pesquisa realizada para compor este documento é verificada que a ordem política nacional sofre com inferências e vaidades pessoais de quem detém o poder, de modo a manterem-se sempre como representantes do povo. 
No ano de 2013 o movimento denominado "o despertar do gigante" despertou os olhares políticos de volta aos detentores reais da soberania do Estado, por tratarse de questão cultural entranhada na sociedade brasileira, fazendo referência aqui aos pequenos atos ímprobos dos brasileiros, sob a justificativa do famoso "jeitinho brasileiro", os problemas não se resolverão da noite para o dia, mas é notório o crescente interesse dos indivíduos pelo que acontece na administração pública.

\section{REFERÊNCIAS}

AMARAL, Roberto. A democracia representativa está morta: viva a democracia participativa! Direito constitucional: estudos em homenagem a Paulo Bonavides | Revista de informação legislativa, v. 38, n. 151, p. 29-65, jul./set. de 2001. Disponível em: <http://www2.senado.gov.br/bdsf/item/id/699>. Acesso em $04 / 2014$.

ARISTÓTELES. A política. Traduzido por Roberto Leal Ferreira. $3^{\circ}$ ed São Paulo: Martins Fontes, 2006.

BARACHO, José Alfredo de Oliveira. Legitimidade do Poder. Revista de informação legislativa, v.22, $\mathrm{n}^{\circ}$ 86, p. 13-28, abr./jun. de 1985. Disponível em <http://www2.senado.gov.br/bdsf/item/id/181611>. Acesso em: 04/2014

BARBOZA, Márcia Noll (Coord.). Cem perguntas e respostas sobre improbidade administrativa: incidência e aplicação da lei n. 8429/1992. Brasília: ESMPU, 2008. Disponível em <http://escola.mpu.mp.br/linha-editorial/outraspublicacoes $/ 100 \% 20$ Perguntas $\% 20$ e $\% 20$ Respostas $\% 20$ versao\%20final\%20EBOOK. pdf>. Acesso em 03/2014.

BOBBIO, Norberto; MATTEUCCI, Nicola; PASQUINO, Gianfranco. Dicionário de política: volume 2: L-Z. 12. ed. Brasília: Universidade de Brasília, 2004.

BODART, Cristiano. Solidariedade Mecânica e Solidariedade Orgânica. Site Café com Sociologia. Disponível em: <http://www.cafecomsociologia.com/2011/01/solidariedade-mecanica-esolidariedade.htm>. Acesso em: 10/2013.

BONAVIDES, Paulo. Ciência Política. 10 ed. São Paulo: Malheiros, 2001.

BONAVIDES, Paulo. Curso de direito constitucional. $28^{\circ}$ ed. atual. São Paulo: Malheiros Editores, 2013.

BONAVIDES, Paulo. Teoria Constitucional da Democracia Participativa. $2^{\circ}$ ed. São Paulo: Malheiros, 2003.

BONAVIDES, Paulo. Teoria do Estado. $7^{\circ}$ ed. São Paulo: Malheiros, 2008.

BRASIL. Constituição da República Federativa do Brasil: atualizada até a Emenda Constitucional n 99. Brasília, DF, 05 de outubro de 1988. Disponível em: 
<http://www.planalto.gov.br/ccivil_03/constituicao/ConstituicaoCompilado.htm>. Acesso em: 20 de janeiro de 2018.

BRASIL. Lei $n^{\circ} 1.079$, de 10 de abril de 1950. Define os crimes de responsabilidade e regula o respectivo processo de julgamento. Diário Oficial da União. Brasília, DF, 12 de abril de 1950.1 Disponível em: <http://www.planalto.gov.br/ccivil_03/leis//1079.htm>. Acesso em 03/2018.

BRASIL. Lei $n^{\circ}$ 8.429, de 02 de junho de 1992. Lei da improbidade administrativa. Dispõe sobre as sanções aplicáveis aos agentes públicos nos casos de enriquecimento ilícito no exercício de mandato, cargo, emprego ou função na administração pública direta, indireta ou fundacional e dá outras providências. Diário Oficial da União. Brasília, DF, 03 de junho de 1992. Disponível em: <http://www.planalto.gov.br/ccivil_03/leis/L8429.htm>. Acesso em 03/2018.

BRASIL. Tribunal Superior Eleitoral. Plebiscitos e referendos. Disponível em <http://www.tse.jus.br/eleicoes/plebiscitos-e-referendos>. Acesso em 02/2018.

BRITO, Maria Orlange. Imunidade Parlamentar no Brasil antes e depois da Emenda Constitucional $n^{\circ}$ 35, de 2001. Revista de informação legislativa, v. 44, n. 173, p. 239-254, jan./mar. 2007. Disponível em: <http://www2.senado.gov.br/bdsf/item/id/141291>. Acesso em 04/2018.

BROSSARD, Paulo. O impeachment. $3^{\circ}$ ed. São Paulo: Saraiva, 1992.

CANOTILHO, José Joaquim Gomes. Direito Constitucional e Teoria da Constituição. $7^{\circ}$ ed. Coimbra: Almedina, 2003.

DALLARI, Dalmo de Abreu. Elementos de Teoria Geral do Estado. 29 ed. São Paulo: Saraiva, 2010.

DALLARI, Dalmo de Abreu. Elementos de Teoria Geral do Estado. $30^{\circ}$ ed. São Paulo: Saraiva, 2011.

DIAS, Danielle S. Soberania: a legitimidade do poder estatal e os novos rumos democráticos. Revista de informação legislativa, v. 48, n. 192, p. 55-66, out./dez. 2011. Disponível em: <http://www2.senado.gov.br/bdsf/item/id/242929>. Acesso em 04/2014.

DICIONÁRIO do pensamento Marxista. Rio de Janeiro: Zahar Editores, 2001.

DUARTE JUNIOR. Ricardo César Ferreira. Democracia Participativa e Regulação Econômica: Uma questão de legitimidade. Dissertação (Mestrado em Direito Constitucional), Universidade Federal do Rio Grande do Norte. Natal, 2013.

FAVER, Marcus. Considerações sobre origem e natureza do impeachment. Disponível em <http://www.tjrj.jus.br/c/document_library/get_file?uuid=b4d02b0bcf66-47e8-8135-5271575f09db\&groupld=10136>. Acesso em 03/2014.

FIGUEIREDO, Paulo de. Impeachment sua necessidade no regime presidencial. Revista de Informação Legislativa. Junho, 1965. Pág 1. Disponível em: <http://www2.senado.gov.br/bdsf/item/id/180677> acesso em 03/2014. 
GÓES, Mauricio Silva de. Impeachment Inglês. Disponível em <http://www.fmr.edu.br/npi/046.pdf>. Acesso em 03/2014.

GOMES, José Jairo. Direito eleitoral. 5. ed. Belo Horizonte: Del Rey, 2010.

KELSEN, Hans. Teoria Geral do Direito e do Estado. Traduzido por Luís Carlos Borges. $3^{\circ}$ Ed. São Paulo: Martins Fontes, 1998.

KELSEN, Hans. Teoria Geral do Direito e do Estado. Traduzido por Luís Carlos Borges. $4^{\circ}$ Ed. São Paulo: Martins Fontes, 2005.

LYRA, Rubens Pinto. Teorias clássicas sobre a democracia direta e a experiência brasileira. Revista de Informação Legislativa, v. 35, n. 140, p. 11-16, out./dez. de 1998. Disponível em: <http://www2.senado.gov.br/bdsf/item/id/413>. Acesso em 03/2014.

MACEDO, Paulo Sérgio Novais de. Democracia Participativa na Constituição Brasileira. Revista de informação legislativa, v.45, no 178, p. 181-193, abr./jun. de 2008. Disponível em: <http://www2.senado.gov.br/bdsf/item/id/176529>. Acesso em $04 / 2014$.

Oficial da União. Decreto $\mathrm{n}^{\circ} 1.550$, de 13 de abril de 1937. Promulga as Convenções sobre direitos e deveres dos Estados e sobre Asilo político, assinadas em Montevidéu a 26 de dezembro de 1933, por ocasião da Sétima Conferencia internacional americana. Diário Oficial da União. Rio de Janeiro, RJ, 19 de abril de 1937. Disponível em <h http://www.planalto.gov.br/ccivil_03/decreto/19301949/d1570.htm>. Acesso em 03/2018.

Oficial da União. Lei $\mathrm{n}^{\circ}$ 9.709, de 18 de novembro de 1998. Regulamenta a execução do disposto nos incisos I, II e III do art. 14 da Constituição Federal. Diário Oficial da União. Brasília, DF, 19 de novembro de 1998. Disponível em: <http://www.planalto.gov.br/ccivil_03/leis/l9709.htm>. Acesso em 02/2018.

Oficial da União. Presidência da República. Ex-presidentes. Disponível em: $<$ http://www.biblioteca.presidencia.gov.br/ex-presidentes/getulio-vargas/biografiaperiodo-presidencial>. Acesso em 04/2018.

PEREIRA, Erick Wilson. Direito Eleitoral: interpretação e aplicação das normas constitucionais-eleitorais. São Paulo: Saraiva, 2010.

REALE, Miguel. Teoria do direito e do estado. $5^{\circ}$ ed. São Paulo: Saraiva, 2000.

RIBEIRO, Fávila. Direito Eleitoral. $4^{\circ}$ ed. Rio de Janeiro: Forense,1996.

SILVA, José Afonso da. Curso de direito constitucional positivo. $36^{\circ}$ ed. São Paulo: Malheiros Editores, 2013.

TAVARES, André Ramos. Curso de direito constitucional. $8^{\circ}$ ed. São Paulo: Saraiva, 2010. 